\title{
A SEROLOGICAL STUDY OF CYSTICERCOSIS IN PATIENTS WITH HIV
}

\author{
Subhash Chandra PARIJA \& A.R. GIREESH
}

\begin{abstract}
SUMMARY
Neurocysticercosis (NCC) has attained the importance of one of the most common cause of focal brain lesions in patients infected with HIV (human immunodeficiency virus). Adequate data regarding the rate of this co-infection is lacking. Therefore, the present study was carried out to determine the prevalence of cysticercosis among HIV patients residing in Puducherry or its neighboring districts of Tamil Nadu State, India. A total of one hundred blood samples were collected from HIV seropositive cases visiting JIPMER hospital, Puducherry, between June 2007 and May 2008. Enzyme immunotransfer blot (EITB) and enzyme linked immunosorbent assay (ELISA) were used to demonstrate anti- T. solium larval stage antibodies and Co-agglutination (Co-A) test was used to detect $T$. solium larval stage antigens in sera. Two HIV seropositive cases were found positive for anti-T. solium larval stage antibody by EITB and four were positive by ELISA. Only one sample was positive by both EITB and ELISA. No serum sample was found positive for T. solium larval stage antigen by Co-A test. The overall seropositivity detected by all the methods was $5 \%$ in this study group. The accurate clinical diagnosis of NCC in HIV is difficult due to deranged immunological parameters in the HIV infected patients. The results of this study provides important data on the prevalence of cysticercosis in HIV positive patients in Puducherry and neighboring areas which was previously unknown. This study will also increase awareness among physicians and public health agencies about $T$. solium cysticercosis in the selected group.
\end{abstract}

KEYWORDS: Cysticercosis; Enzyme immunotransfer blot; Enzyme linked immunosorbent assay; Co-agglutination test; HIV positive patients.

\section{INTRODUCTION}

Cysticercosis, a disease caused by the larval stage of cestode parasite Taenia solium is widely prevalent in human and porcine hosts in many developing countries of Latin America, Africa and Asia ${ }^{7}$. Approximately 50 million people are infected with $T$. solium and about 50,000 deaths occur due to this disease worldwide every year ${ }^{4}$. Human cysticercosis results from the ingestion of food, water and vegetables contaminated with T. solium eggs or even by autoinfection in case of persons with intestinal taeniasis. The central nervous system (CNS) is the most common site of severe symptomatic infection where the condition is referred to as $\mathrm{NCC}^{23}$.

Due to the increased frequency of HIV infection, cysticercosis has become one of the most frequent opportunistic infections and the most common cause of focal brain lesions in patients infected with HIV ${ }^{\mathbf{1 0 , 1 1}}$. Furthermore, cysticercosis is endemic in many regions of the world and more common in pig eating countries with low socioeconomic status and poor sanitation ${ }^{3}$. HIV infection is a serious problem in the present day world wide. A high rate of infection is found in many regions of the world, including India ${ }^{17}$. One of the major health problems among
HIV seropositive patients is superimposed infections due to the defect in immunity ${ }^{15}$. The increasing frequency of HIV infection in endemic areas of cysticercosis may increase this co-infection. Only few cases of cysticercosis in HIV - infected patients have been reported, and the influence of HIV infection on the natural history of cysticercosis is yet to be defined. We therefore conducted this study specifically to determine the seroprevalence of cysticercosis in HIV seropositive cases residing in Puducherry or its neighboring districts of Tamil Nadu State for specific $T$. solium larval stage antigens and anti-T. solium larval stage antibodies using immunological techniques developed and evaluated in this laboratory.

\section{MATERIALS AND METHODS}

Study group: A total of one hundred serum samples from HIV seropositive cases were analyzed. This study was carried out in the Out Patient Department and Inpatient wards of Medicine and Neurology in Jawaharlal Institute of Postgraduate Medical Education and Research (JIPMER) hospital, Puducherry, India. Serum samples collected from the patients were screened for antibodies against HIV by ELISA and confirmed by Western blot. 
Controls: Sera collected from known positive NCC cases (confirmed by MRI, EITB and ELISA) were used as positive control ( $\mathrm{n}=16$ definitive diagnosis group, as per the diagnostic criteria for the diagnosis of NCC by DEL BRUTTO et al. in 2001) ${ }^{7}$. For negative control, sera collected from normal healthy individuals were used $(n=25)$. Sera collected from patients with hydatidosis were used to detect the cross reactivity $(\mathrm{n}=$ 15). For Co-A test, $10 \mu \mathrm{L}$ of total soluble protein antigen of $T$. solium larval stage was added to $90 \mu \mathrm{L}$ of phosphate buffered saline (PBS) $\mathrm{pH}$ 7.2 (1:10) which was further diluted to 1:1280 using PBS pH 7.2. This was taken as positive control. Informed consent was obtained from all subjects in this group.

Preparation of the $T$. solium larval stage antigens: The $T$. solium larval stage was collected from the tissue of naturally infected pig, which were dissected free from surrounding tissue into sterile PBS pH 7.2 containing $40 \mathrm{mg}$ each of kanamycin, nalidixic acid and ampicillin with protease inhibitor, phenylmethylsulphonyl fluoride (PMSF) $(0.006 \%)$ at room temperature. Whole cysts after removing the cyst fluid were taken to prepare the complete somatic homogenate antigen as per the method described by SREENIVASAMURTHY et al., 199927. Ten grams of ruptured whole cysts were homogenized manually in glass tissue homogenizer with PBS ( $\mathrm{pH} 7.2)$ containing PMSF $(0.1 \mathrm{mM})$ at $4{ }^{\circ} \mathrm{C}$. The homogenate was further subjected to sonication, eight times at $12 \mathrm{kHz}$ with 30 seconds cooling interval on an ice bath. The homogenate was centrifuged at $4{ }^{\circ} \mathrm{C}$ for 30 minutes at 15,000 rpm in refrigerated centrifuge. The supernatant was used as the $T$. solium larval stage somatic antigen ${ }^{27}$. The protein analysis of complete somatic homogenate was carried out by standard procedure described by LOWRY et al., $1951^{16}$.

\section{ANTIBODY DETECTION}

Sodium dodecyl sulfate-polyacrylamide gel electrophoresis (SDS-PAGE): SDS-PAGE was indicated for analyzing the protein profile of the antigen, by characterizing \& separating proteins based on their molecular weight. Briefly, the metacestode antigen was subjected to SDS-PAGE in $10 \%$ gel for resolving the antigenic peptides using a submerged gel electrophoresis apparatus (Bangalore Genei, India) using standard protocol ${ }^{24}$. The antigen preparations were separated under non-reducing conditions by sodium dodecyl sulfate-polyacrylamide gel electrophoresis gradient gels on $10 \times 8 \mathrm{~cm}$ (1-mm thick) mini-gels (Bangalore Genei, India). The gels were stained with Coomassie Brilliant Blue and molecular weight was determined using standard molecular weight markers (Bangalore Genei, India) ${ }^{30}$.

Enzyme immuno transfer blot: The glycoprotein antigen used in EITB was prepared by using metacestodes obtained from naturally infected pig to analyze the antibody response. For immunoblotting analysis, the separated antigens mentioned above were electrophoretically transferred to a $0.22-\mu \mathrm{m}$-pore-size nitrocellulose membrane (NCM) (Pierce, Rockford) in a mini-Transblot cell (Pharmacia Biotech, USA). The free binding sites were blocked by treatment with $3 \%$ bovine serum albumin (BSA) in PBS for two h and washed in PBS containing 0.1\% Tween 20. Analysis was carried out with human sera diluted 1:100 in PBS (pH 7.2) containing 0.1\% Tween 20 (PBST) ${ }^{30}$. Horseradish peroxidase-conjugated goat antibody to human $\mathrm{IgG}$ diluted 1:1000 (Bangalore Genei), was used as secondary antibody. Antibody reactivity was visualized with a substrate solution containing diaminobenzidine
(Pierce, Perbio) $(6 \mathrm{mg} / \mathrm{mL}$ in PBS containing one $\mathrm{mL}$ of $30 \%$ hydrogen peroxide $(\text { Sigma })^{2}$.

Enzyme linked immunosorbent assay: ELISA was performed as per the procedure described by standard method of Crowther with few modifications ${ }^{6}$. Briefly, one $\mu$ g protein per $100 \mu \mathrm{L}$ concentration of the antigen was prepared in antigen coating buffer (PBS pH 7.2) as per the method described earlier and used for coating plates (NUNC) followed by blocking non-specific binding sites by $2 \%$ BSA in PBS ( $\mathrm{pH}$ 7.2). Optimum dilution (1:50) of test serum sample and known $T$. solium larval stage antibody-positive serum samples were prepared in sample dilution buffer, added in duplicate in the wells, and goat antihuman-IgG-HRP conjugated secondary antibody (Bangalore Genei, India) was added to each well for detection. Substrate solution prepared freshly by adding six mg of OPD in $10 \mathrm{~mL}$ of PBS pH 7.2 and $10 \mu \mathrm{L}$ of $\mathrm{H}_{2} \mathrm{O}_{2}(30 \%)$ was added just before to use. The reaction was stopped by adding $50 \mu \mathrm{L}$ of $2 \mathrm{~N} \mathrm{H}_{2} \mathrm{SO}_{4}$ in each well to avoid over reaction and development of optimum colour ${ }^{9}$. The absorbance was taken at 492 $\mathrm{nm}$ in an ELISA reader (BIO RAD). Various controls were used for validity of the assay such as antigen blank, antibody blank, negative control serum, and known positive control serum. Serum sample which gave OD492 value of more than cut-off (mean of 50 negative serum samples $+2 \mathrm{SD}$ ) was considered as positive. The cut-off used in the present study was 0.157 .

\section{ANTIGEN DETECTION}

Co-agglutination test: Co-A test to detect $T$. solium larval stage antigen in the serum was carried out as per the method described by us before ${ }^{20}$. In this test Cowan's strain of Staphylococcus aureus rich in Protein A (SAPA) cells, sensitized with polyclonal antibodies (hyperimmune serum against $T$. solium larval stage) were used to detect specific $T$. solium larval stage antigen in the serum. The hyperimmune serum was used at the concentration of $100 \mu \mathrm{L} / 10 \mathrm{~mL}$ of SAPA cells suspension (1\%) as the optimal sensitizing dose (OSD). Hyperimmune serum against $T$. solium larval stage whole cyst antigen (total soluble protein antigen) was raised in white New Zealand rabbit in divided doses with Freund's complete adjuvant in the primary dose and with incomplete adjuvant in the booster doses. The IgG fraction from the immune serum was purified by precipitation with cold saturated ammonium sulphate by the method of GOTTSTEIN ${ }^{14}$.

The test was performed as per the procedure described by SHARIFF \& PARIJA $(1993)^{26}$. Sensitization of these cells was done by adding 0.1 $\mathrm{mL}$ of rabbit antisera to one $\mathrm{mL}$ of $10 \%$ Staphylococcal suspension and incubated for 30 minutes at $37{ }^{\circ} \mathrm{C}$ in water bath. These incubated cells were washed in PBS and re-suspended to a concentration of $2 \%$ in PBS 7.2 with $0.1 \%$ sodium azide. The test was performed on glass slides, which were divided with a glass marking pencil into two equal halves. $25 \mu \mathrm{L}$ of the test serum sample was placed on each half of the slide. An equal volume $(25 \mu \mathrm{L})$ of sensitized SAPA cell suspension was added to the serum on one half. The same volume $(25 \mu \mathrm{L})$ of a $2 \%$ suspension of unsensitized SAPA cells was added to the serum on the half as a cell control. The slide was then rotated manually for two min and then observed. In a positive Co-A test, the addition of sensitized SAPA cells to the test serum resulted in the formation of large visible clumps of bacterial cells within two min; in a negative reaction, no visible clumping was observed. Agglutination with the sensitized cells and not with the 
unsensitized cells was considered to be a positive result. It is a qualitative test, so there is no cut-off used.

\section{RESULTS}

SDS PAGE \& enzyme immunotransfer blot: In the present study the high molecular weight antigenic peptides were observed to be reactive and specific to patient sera more frequently than the low molecular weight antigenic peptides when $T$. solium larval stage somatic antigens were used. A total of six major bands were detected in the T. solium larval stage antigen in the SDS-PAGE profile. The major antigenic peptides were found to be $100 \mathrm{kDa}, 75 \mathrm{kDa}, 67.74 \mathrm{kDa}, 51.6 \mathrm{kDa}, 47 \mathrm{kDa}, 43.5 \mathrm{kDa}$. Only two antigenic peptides, i.e. the $75 \mathrm{kDa}, 67.74 \mathrm{kDa}$, were demonstrated by the EITB in serum samples. Of 100 serum samples tested, two $(2 \%)$ had anti-T. solium larval stage antibodies. The antibody to $T$. solium larval stage somatic antigen reacting with one or more of these peptides in the serum was considered positive by the test.

Enzyme linked immunosorbent assay: ELISA demonstrated reactive $T$. solium larval stage antibody titre in four (4\%) serum samples collected from HIV seropositive cases. The cut-off $\mathrm{OD}_{492}$ values of the ELISA using T. solium larval stage somatic antigen was used to detect IgG antibodies in the serum. The test detected antibodies in sera from known positive controls and did not show any antibodies in the sera of negative controls and patients with hydatid disease.

Co-agglutination test: The Co-A detected T. solium larval stage antigen in none of the serum samples out of total 100 HIV seropositive cases. The results were compared with that of EITB for detection of antibodies. Among these samples two (2\%) were positive for anti-T. solium larval stage antibody by EITB and four (4\%) were positive for antibodies by ELISA. Only one sample was found positive in both tests indicative of a low concordance between the two assays. Thus, overall five samples were positive for anti-T. solium larval stage antibodies. The antigen detection limit of the Co-A test using the particular batch of reagent preparation was found to be up to $0.27 \mu \mathrm{g}^{21}$.

\section{DISCUSSION}

Relatively few cases of HIV and NCC co-infection have been reported, even in areas where there is high prevalence of both diseases individually $y^{5,25,28,29}$. In a study conducted in Mexico only $1.1 \%$ of NCC has been reported in HIV positive cases, compared with $2.4 \%$ in control autopsies ${ }^{15}$. In South Africa, co-infections by HIV, M. tuberculosis, and T. solium are relatively common in densely populated area where the parasite is widely distributed ${ }^{18}$. NCC has been reported in HIV cases traveling to areas with high intensity of cysticercosis ${ }^{29}$. In this report HIV test serology was positive by ELISA and Western blot and the CD4+ T-lymphocyte count was 473 cells/ $\mu$ L. SERPA et al. (2007) reported NCC as a fatal infection in a HIV infected Colombian immigrant at Spain $^{10}$. An unusual form of epidural spinal racemose NCC revealed by compression of Cauda equina in a HIV infected man was reported in France. SERPA et al. (2007) ${ }^{25}$ identified 27 cases of NCC-HIV coinfection in Houston. The most frequent presentation (61\%) was with multiple parenchymal lesions ${ }^{8}$. Similarly, NCC and HIV co-infection are reported from different areas of the world including, Italy, Ecuador, Mexico and Zimbabwe $\mathrm{e}^{10,11,25,28,29}$. However, little is known about the association of HIV and the clinical course of cysticercosis. Concurrent infection with $T$. solium and HIV would be expected to occur more frequently because of the increasing frequency of HIV infection in India where cysticercosis is endemic.

In the present study EITB and ELISA were used to detect anti-T. solium larval stage antibody in patients with HIV. In most of the studies sensitivity and specificity of EITB reported was $98 \%$ and $100 \%$ respectively ${ }^{1,3,13}$. Many of the investigators have found a varying sensitivity and specificity with ELISA test for detection of anti-T. solium larval stage antibody, using different antigenic preparations ${ }^{19}$. However, ELISA and EITB are the most frequently used tests in recent times. By using EITB and ELISA, 5\% serum samples were positive for anti-T. solium larval stage antibody in HIV cases. The anti-T. solium larval stage antibody positive cases were from Villupuram, Cuddalore, Thiruvannamalai districts that are immediately neighboring to Puducherry where pig farming is commonly done.

Among the anti-T. solium larval stage antibody positive cases, none of them were presenting the symptoms of NCC or other form of cysticercosis. The presence of anti-T. solium larval stage antibodies in five cases indicates that the cases either have suffered from cysticercosis in past or having an infection with no overt clinical manifestations. In this study the seroprevalence of cysticercosis was less in HIV patients compared to non HIV infected individuals $(6.1 \%)^{22}$. This apparently lower prevalence in this population may be due to absent or low immune response in patients with HIV or the cystic stages of the parasite may not evoke a strong detectable antibody response while they remain alive and intact.

T. solium larval stage antigen was detected by Co-A test in $57 \%$ of cysticercosis cases with hyperimmune sera raised to whole cyst antigen in the previous studies ${ }^{20,21,22}$. An interesting finding was that none of the HIV seropositive cases were positive for T. solium larval stage antigen. The failure of Co-A in these cases to detect antigen could be either due to the absence of antigen in the serum, or antigen concentration that were below detection limit of the assay or as a result of degradation of antigen during storage of the serum at $-20^{\circ} \mathrm{C}$.

Diagnosis of cysticercosis in HIV patients is very important, because tuberculous meningitis and toxoplasmosis are very common in this group which mimics $\mathrm{NCC}^{32}$. So a consideration of cysticercosis in this group of patients can help in early diagnosis. Detection of the antibodies in the serum to $T$. solium larval stage antigens is the most commonly used and convenient method for the laboratory diagnosis of cysticercosis ${ }^{31}$. As the immune response is lowered in HIV positive patients the sensitivity of antibody detection may be reduced in this group of patients. Symptomatic cysticercosis largely depends on the host inflammatory response ${ }^{33}$. Decreased cell-mediated immunity characteristic of advanced HIV infection makes cysticercosis more likely to remain asymptomatic ${ }^{31,32}$. In sero-diagnosis the initially reported high sensitivity and specificity of the EITB assay may be ambiguous to detect antibody in this study group. So the result of EITB assay may be more reliable in patients with AIDS, in combination with radiographic and clinical data.

\section{CONCLUSION}

This study provides important data on the sero-prevalence of $T$. solium cysticercosis in HIV positive patients in Puducherry and neighboring 
areas which was previously unknown. This population is at risk for $T$. solium cysticercosis where the parasite affects the immune response of the host. We hope this study will increase awareness among physicians and public health agencies about $T$. solium cysticercosis in the selected group. As the incidence of HIV is increasing in endemic areas of cysticercosis, simultaneous diagnosis of both diseases is an event to be expected.

\section{RESUMO}

\section{Estudo sorológico da cisticercose em pacientes com HIV}

Neurocisticercose (NCC) tem alcançado a importância de uma das mais comuns causas de lesões focais no cérebro em pacientes infectados pelo HIV (vírus da imunodeficiência adquirida). Dados adequados relativos à frequencia desta co-infecção estão faltando. Portanto, o presente estudo foi realizado para determinar a prevalência da cisticercose entre pacientes com HIV residindo em Puducherry ou distritos vizinhos do Estado de Tamil Nadu, India. Um total de cem amostras foram coletadas de casos soropositivos do Hospital JIPMER, Puducherry, entre junho de 2007 e maio de 2008. "Enzyme immunotransfer blot" (EITB) e ELISA foram utilizados para demonstrar anticorpos contra a fase larval do T. solium. Testes de co-aglutinação (Co-a) foram usados para demonstrar antígenos da fase larval do T. solium no soro. Dois casos HIV soropositivos foram positivos para anticorpos contra a fase larval do T. solium por EITB e quatro foram positivos por ELISA. Somente uma amostra foi positiva por ambos EITB e ELISA. Nenhuma amostra de soro foi positiva para antígeno da fase larval do T. solium pelo teste Co-a. A soropositividade total detectada por todos os métodos foi $5 \%$ neste grupo de estudo. O diagnóstico clínico exato de NCC em HIV é difícil devido aos desordenados parâmetros imunológicos nos pacientes infectados pelo HIV. Os resultados deste estudo fornecem dados importantes sobre a prevalência da cisticercose em pacientes HIV positivos em Puducherry e áreas vizinhas que eram previamente desconhecidos. Este estudo também aumentará a atenção dos médicos e agências de saúde pública sobre a cisticercose por T. solium em grupo selecionado.

\section{REFERENCES}

1. ANSARI, J.A.; KARKI, P.; DWIVEDI, S. et al. - Neurocysticercosis: a review. Kathmandu Univ. med. J., 1: 48-55, 2003.

2. BARCELOS, I.S.; MINEO, J.R.; DE OLIVEIRA SILVA, D.A. et al. - Detection of IgG in cerebrospinal fluid for diagnosis of NCC: evaluation of saline and SDS extracts from Taenia solium and Taenia crassiceps metacestodes by ELISA and immunoblot assay. Trop. Med. int. Hlth, 6: 219-226, 2001.

3. BUENO, E.C.; VAZ, A.J.; MACHADO, L.D. \& LIVRAMENTO, J.A. - Neurocysticercosis: detection of $\operatorname{IgG}, \operatorname{IgA}$ and $\operatorname{IgE}$ antibodies in cerebrospinal fluid, serum and saliva samples by ELISA with Taenia solium and Taenia crassiceps antigens. Arq. Neuropsiquiat., 58: 18-24, 2000.

4. COMMISSION ON TROPICAL DISEASES OF THE INTERNATIONAL LEAGUE AGAINST EPILEPSY - Relationship between epilepsy and tropical diseases. Epilepsy, 35: 88-93, 1994.

5. CHIANURA, L.; SBERNA, M.; MOIOLI, C. et al. - Neurocysticercosis and human immunodeficiency virus infection: a case report. J. Travel Med., 13: 376-380, 2006.

6. CROWTHER, J.R. - ELISA. Theory and practice. Meth. molec. Biol., 42: 1-218, 1995.

7. DEL BRUTTO, O.H.; RAJSHEKHAR, V.; WHITE A.C. et al. - Proposed diagnostic criteria for neurocysticercosis. Neurology, 57: 177-183, 2001.
8. DELOBEL, P.; SIGNATE, A.; EL GUEDJ, M. et al. - Unusual form of neurocysticercosis associated with HIV infection. Europ. J. Neurol., 11: 55-58, 2004.

9. D'SOUZA, P.E. \& HAFEEZ, M. - Detection of Taenia solium cysticercosis in pigs by ELISA with an excretory - secretory antigen. Vet. Res. Commun., 23: 293-298, 1999.

10. FOYACA-SIBAT, H. \& IBAÑEZ-VALDÉS, L. de F. - Intraventricular neurocysticercosis in HIV positive patients. Internet J. Neurol., 2(1), 2003.

11. FOYACA-SIBAT, H. \& IBAÑEZ-VALDES, L. de F. - Neurocysticercosis in HIV-positive patients. Internet J. infect. Dis., 2(2), 2003.

12. GARCÍA, H.H.; GONZALEZ, A.E.; EVANS, C.A.W. \& GILMAN, R.H. - Taenia solium cysticercosis. Lancet, 362: 547-556, 2003.

13. GEKELER, F.; EICHENLAUB, S.; MENDOZA, E.G. et al. - Sensitivity and specificity of ELISA and immunoblot for diagnosing neurocysticercosis. Europ. J. clin. Microbiol. infect. Dis., 21: 227-229, 2002.

14. GOTTSTEIN, B. - An immunoassay for the detection of circulating antigens in human echinococcosis. Amer. J. trop. Med. Hyg., 33: 1185-1190, 1984

15. JESSURUN, J.; BARRÓN-RODRÍGUEZ, L.P.; FERNÁNDEZ-TINOCO, G. \& HERNÁNDEZ-AVILA, M. - The prevalence of invasive amebiasis is not increased in patients with AIDS. AIDS, 6: 307-309, 1992.

16. LOWRY, O.H.; ROSEBROUGH, N.J.; FARR, A.L. \& RANDALL, R.J. - Protein measurement with folin phenol reagent. J. biol. Chem., 193: 265-275, 1951.

17. MATHEW, M.J. \& CHANDY, M.J. - Central nervous system toxoplasmosis in acquired immunodeficiency syndrome: an emerging disease in India. Neurology India, 47: 182-187, 1999.

18. MODI, M.; MOCHAN, A. \& MODI, G. - Management of HIV-associated focal brain lesions in developing countries. Q. J. Med., 97: 413-421, 2004.

19. PROAÑO-NARVAEZ, J.V.; MEZA-LUCAS,A.; MATA-RUIZ, O.; GARCÍA-JERÓNIMO, R.C. \& CORREA, D. - Laboratory diagnosis of human neurocysticercosis: doubleblind comparison of enzyme-linked immunosorbent assay and electroimmunotransfer blot assay. J. clin. Microbiol., 40: 2115-2118, 2002.

20. PARIJA, M.; BISWAS, R; HARISH, B.N. \& PARIJA, S.C. - Detection of specific Cysticercus antigen in the urine for diagnosis of neurocysticercosis. Acta trop., 92: 253-260, 2004.

21. PARIJA, S.C.; SAHU, P.S. \& DHANYA, H. - Detection of Cysticercus antigens and antibodies in cerebrospinal fluid of patients with chronic meningitis. Rev. Inst. Med. trop. S. Paulo, 49: 331-334, 2007

22. PARIJA, S.C. \& SAHU, P.S. - A serological study of human cysticercosis in Pondicherry, South India. J. commun. Dis., 35: 283-289, 2003.

23. PARIJA, S.C; BALAMURUGAN, N.; SAHU, P.S. \& SUBBAIAH, S.P. - Cysticercus antibodies and antigens in serum from blood donors from Pondicherry, India. Rev. Inst. Med. trop. S. Paulo, 47: 227-230, 2005.

24. SAMBROOK, J.; FRITSCH, E.F. \& MANIATIS, T. - Molecular cloning: a laboratory manual. 2. ed. New York, Cold Spring Harbor, 1989.

25. SERPA, J.A.; MORAN, A.; GOODMAN, J.C.; GIORDANO, T.P. \& WHITE Jr., C. Neurocysticercosis in the HIV era: a case report and review of the literature. Amer. J. trop. Med. Hyg., 77: 113-117, 2007.

26. SHARIFF, G.M. \& PARIJA, S.C. - Co-agglutination (Co-A) test for circulating antigen in hydatid disease. J. med. Microbiol., 38: 391-394, 1993.

27. SREENIVASAMURTHY, G.S.; D`SOUZA, P.E. \& JAGANNATH, M.S. - Enzyme-linked immuno electro transfer blot in diagnosis of Taenia solium cysticercosis in pigs. J. paras. Dis., 23: 85-88, 1999. 
28. SOTO-HERNANDEZ, J.L.; OSTROSKY-ZEICHNER, L.; TAVERA, G. \& GOMEZ AVIÑA, A. - Neurocysticercosis and HIV infection: report of two cases and review. Surg. Neurol., 45: 57-61, 1996

29. THORNTON, C.A.; HOUSTON, S. \& LATIF, A.S. - Neurocysticercosis and human immunodeficiency virus infection: a possible association. Arch. Neurol., 49: 963$965,1992$.

30. TOWBIN, H.; STAEHELIN, T. \& GORDON, J. - Electrophoretic transfer of proteins from polyacrylamide gel to nitrocellulose sheets: procedure and cone applications. Proc. nat. Acad. Sci. (Wash.), 76: 4350-4354, 1979.
31. TSANG, V.C.; BRAND, J.A. \& BOYER, A.E. - An enzyme-linked immunoelectrotransfer blot assay and glycoprotein antigens for diagnosing human cysticercosis (Taenia solium). J. infect. Dis., 159: 50-59, 1989.

32. WHITE Jr., A.C.; DAKIK, H. \& DIAZ, P. - Asymptomatic neurocysticercosis in a patient with AIDS and cryptococcal meningitis. Amer. J. Med., 99: 101-102, 1995.

33. WHITE Jr., A.C.; ROBINSON, P. \& KUHN, R. - Taenia solium cysticercosis: host-parasite interactions and the immune response. Chem. Immunol., 66: 209-302, 1997.

Received: 26 May 2008

Accepted: 18 June 2009 